PERM JOURNAL OF PETROLEUM AND MINING ENGINEERING

ВЕСТНИК ПНИІУ. ГЕОЛОГИЯ. НЕФТЕААЗОВОЕ И ГОРНОЕ ДЕЈЮ

ISSN 2224-9923

Volume/Toм 18 №1, 2018

http://vestnik,pstu.ru/geo/

УДК 622.276.5:550.8

Article / Статья

(C) PNRPU / ПНИПУ, 2018

\title{
THE DESIGN OF GEOLOGICAL EXPLORATION WITH SIDE TRACK DRILLING
}

\section{Stanislav V. Varushkin, Zhanna A. Khakimova}

LUKOIL-PERM LLC (62 Lenina st., Perm, 614990, Russian Federation)

\section{ПРОЕКТИРОВАНИЕ ГЕОЛОГО-РАЗВЕДОЧНЫХ РАБОТ МЕТОДОМ СТРОИТЕЛЬСТВА БОКОВЫХ СТВОЛОВ}

\section{С.В. Варушкин, Ж.А. Хакимова}

ООО «ЛУКОЙЛ-ПЕРМЬ» (614990, Россия, г. Пермь, ул. Ленина, 62)

Received / Получена: 24.04.2018. Accepted / Принята: 03.09.2018. Published / Опубликована: 28.09.2018

Key words:

geological exploration, side track, 3D seismic exploration, structures, candidate wells, geodata, profile, land acquisition, "window" cutting, geophysical surveys, core sampling, reserves increase, field, costs

\begin{abstract}
The paper discusses the method of well reconstruction using sidetracks drilling as a method for searching prospective formations in Perm region. At the moment, there are small-size reservoirs of less than 100 thousand tonnes of resources included in located and prepared formations. Drilling of the reservoirs is unprofitable. Drilling a sidetrack from wells located near promising reservoirs can be more economical way to solve the problem.

Drilling of sidetracks has become one of the most investment-attractive technologies aimed at stabilizing and further increasing oil production from fields being developed. This method is used to intensify the system of field development, increase the rate of oil extraction from productive formations and actually replaces the compaction of the well grid. Appropriate technologies help to save a well as well as construction and development costs. In presence of candidate wells, including plugged and abandoned one, located near promising structures, it becomes important to search for them using sidetrack drilling as a method of geological exploration.

The paper describes the technology of side tracks construction and presents the algorithm of works designed. Well stock of LUKOIL-PERM LLC and geological structure of promising objects were analyzed. The technical possibility of well reconstruction by sidetracking was considered. Criteria for candidate wells and "window" kickoff intervals to be selected are defined. Calculation of profiles of second well bores for recommended wells was made, various aspects related to their construction were worked out. As a result of the work it was proposed to include these activities in the geological exploration program of LUKOIL-PERM LLC.

Results of the work have practical significance and can be used in production activities of oil and gas companies.
\end{abstract}

Ключевые слова: геолого-разведочные работы, боковой ствол, сейсморазведочные работы 3D, структуры, скважины-кандидаты, геоданные, профиль, отвод земли, зарезка «окна», геофизические исследования, отбор керна, прирост запасов, месторождение, затраты.

\begin{abstract}
Рассмотрен вопрос использования метода реконструкции скважины путем бурения боковых стволов как способа для опоискования перспективных структур на территории Пермского края. В настоящий момент в фонде выявленных и подготовленных структур числятся малоразмерные объекты с ресурсами менее 100 тыс. т, ввод в бурение которых экономически нерентабелен. Решением этой проблемы может стать более экономичный способ бурение бокового ствола из скважин, расположенных вблизи перспективных объектов.

Бурение боковых стволов стало одной из наиболее инвестиционно привлекательных технологий, направленных на стабилизацию и дальнейший рост добычи нефти на разрабатываемых месторождениях. Данный метод служит для интенсификации системы разработки месторождений, увеличения коэффициента извлечения нефти из продуктивных пластов и фактически заменяет уплотнение сетки скважин. Соответствующие технологии помогают сохранить скважину и сэкономить затраты на строительство и освоение. При наличии скважин-кандидатов, в том числе консервированных и ликвидированных, расположенных вблизи перспективных структур, становится актуальным их опоискование с помощью строительства бокового ствола как метода геолого-разведочных работ.

В работе описана технология строительства боковых стволов и представлен алгоритм проектируемых работ. Проанализированы фонд скважин ООО «ЛУКОЙЛ-ПЕРМЬ» и геологическое строение перспективных объектов. Рассмотрена техническая возможность реконструкции скважин бурением боковых стволов. Определены критерии выбора скважин-кандидатов и интервалов зарезки «окна». Произведен расчет профилей вторых стволов для рекомендуемых скважин, проработаны различные аспекты, связанные с их строительством. Конечным итогом работы стали предложения по включению данных мероприятий в программу геолого-разведочных работ ООО «ЛУКОЙЛ-ПЕРМЬ».

Результаты работы имеют практическую значимость и могут быть использованы в производственной деятельности нефтегазодобывающих обществ.
\end{abstract}

\footnotetext{
Stanislav V. Varushkin (Author ID in Scopus: 890229) $-1^{\text {st }}$ category Geologist of the Geology Department (tel.: +007 3422198000 , e-mail: Stanislav.Varushkin2@lp.lukoil.com). The contact person for correspondence.

Zhanna A. Khakimova - Senior Geologist of the Geology Department (tel.: +007 34223566 48, e-mail: Zhanna.Khakimova@lp.lukoil.com).

Варушкин Станислав Владимирович - геолог 1-й категории Управления геологии (тел.: +007 34221980 00, e-mail: Stanislav.Varushkin2@lp.lukoil.com). Контактное лицо для переписки.
}

Хакимова Жанна Александровна - ведущий геолог Управления геологии (тел.: +007 342235 66 48, e-mail: Zhanna.Khakimova@lp.lukoil.com). 


\section{Introduction}

Geological departmet of any oil and gas production enterprise is considered to be effective if it prepares necessary information for the development of long, medium and short time planning and geological exploration programs, which is the main criterion. In order to compensate oil production by increasing reserves through geological exploration today, it is necessary to intensify work both on the study of territories and formations that were not fully explored yet and on the development of new directions and ways of geological survey [1-7].

During the planning of exploration and appraisal drilling license obligations and terms in geological projects, which are subsequently laid into the program of geological exploration must be taken into account. Often, due to investment unattractiveness additional exploration can be postponed from one year to another.

Sidetrack drilling plays a significant role in development of oil and gas fields among the modern methods. Their use allows us to solve a large range of problems associated with the increase in oil production on fields that are at a late stage of development and the involvement of hardto-recover hydrocarbon reserves. Appropriate technologies help to save the well and costs for its development [8-13].

\section{Sidetrack drilling technology}

Sidetracking is an effective technology that allows increasing oil production at old fields and the coefficient of oil extraction from reservoirs, to return to operation oil wells that could not be returned to the existing stock by other methods. [14-16].

Sidetracking allows to involve reservoir areas that were not in production previously, hard-torecover oil reserves, extraction of which was not previously been possible. Sidetracking technology contributes to increased oil recovery and actually replaces well grid compaction.
Besides, there are examples of additional exploration of missed deposits and local structures identified according to $3 \mathrm{D}$ seismic survey data [17].

Sidetracking consists of the following steps:

- selection of candidate wells for sidetracking;

- selection of structure, profile and calculation of the sidetracks' trajectory;

- elimination of a part of the wellbore;

- cutting the "window" in the casing;

- kickoff and drilling of sidetracks;

- fastening with a shank or filter;

- development and bringing the well on line of the influx of formation fluid.

Production columns above the cement bridge installation interval, according to the relevant instruments and pressure testing, must be technically efficient, trajectories of selected and neighboring wells must be sufficiently reliable to prevent the wells from crossing [18].

Well design in terms of reliability, manufacturability and safety should ensure:

1. Maximum utilization of the reservoir energy of the productive formation during operation due to selection of the optimal diameter of the production string and the possibility of achieving the design level of hydrodynamic communication of productive deposits with the wellbore.

2. Use of optimal modes of operation, maintaining reservoir pressure, heat exposure and other methods of enhanced oil recovery.

3. Conditions for safe work without accidents and problems at all stages of well construction and operation.

4. Required geological information on the open section.

5. Conditions for the protection of the subsoil and the environment due to the strength and durability of lining the well, the tightness of casing and annular spaces.

6. Maximum alignment by type of casing and wellbore.

Side trunks are designed to be drilled from wells cased with $146 \mathrm{~mm}$ diameters. For them, 
casing of countersunk column liners with diameters $101.6 \mathrm{~mm}$ is recommended [19-22].

The main option of sidetracking is to cut the "window". A wedge-diverter with an orienting device, which is installed on an artificial face, goes down the well. Work on the descent and installation of the wedge-diverter is performed in accordance with the technology of manufacturers.

Lowering the assembly on steel drill pipes is made with the measurement of the tool length, with a speed of not more than $0.2 \mathrm{~m} / \mathrm{s}$. In directional wells wedge-diverter should be installed approximately within $\pm 90^{\circ}$ with respect to the azimuth of the main shaft curvature at the installation site [23].

After whipstock is installed the assembly with the suspension device and the telesystem rises, the assembly for cutting the "window" goes down.v.

\section{Workover planning algorithm}

At the first stage, based on actual geological material on 3D seismic survey promising areas and structures was selected. It is proposed to use preserved and abandoned wells located close to the contour or set of prospective uplift as candidate wells. It is worth saying that approaches to well abandonment did not take into account the possible prospects for their bringing back to production when there is a change in ideas about a formation geological structure.

As an example of planning, southern dome of the Gubanovskaya structure, located in the southern part of the Veslyanskaya ridge-like zone in the Kokuyskoe field (Fig. 1).

The structure was ready in 2015 based on the results of seismic prospecting using the method of a common depth point of $3 \mathrm{D}$ at the Kokuyskoe field (SP 12/13). The amplitude of the structure in the reflecting formation $\mathrm{II}^{\Pi}$ is $14 \mathrm{~m}$, dimensions $-1.5 \times 0.8 \mathrm{~km}$. The formation represents a tectonic-sedimentary uplift modifyed by Late Devonian organogenic structure, paleokarst in Tournaisian and Bashkir sediments. There is Well 754 of the Kokuyskoe field drilled near by the structure.

In order to search for oil deposits, it is recommended to drill a sidetrack in Well 754-Kokuyskoe on Frasnian deposits. The recoverable resources on the passport are 328 thousand tons. Resources of the following complexes are estimated: Upper Devonian, Lower Carboniferous Carbonate and Visean Terrigenous. In addition, the structure falls into the zone of reserves of categories $\mathrm{B} 1+\mathrm{C} 1$ that have already been put on the balance of Middle-Carboniferous sediments.

At the second stage, the technical state of the well and possibility of overhaul are considered. On the basis of the regulations [24] and production experience of the company, the criteria for selecting candidate wells and sidetracking intervals are substantiated. Reasons why the well was subjected to temporary suspension/abandonment, oil production string tightness, open perforation intervals, test results and other aspects are considered (Table 1).

The main criteria for the selection of wells for their recovery by sidetrack drilling according to the analysis are (Fig. 2):

- absence of remaining reserves in a well;

- current bottomehole location does not exceed $700 \mathrm{~m}$ from the optimal (proposed) on the structure arch;

- leaktightness of the production string;

- borehole profile, allowing to carry out works on the second borehole (intensity of curvature less than $5^{\circ}$ by 10 meters);

- absence of metal patches or cuffs from the pipes above the estimated point of the second sidetrack cutting (the maximum cutting depth of the "window" is $400 \mathrm{~m}$ above the roof of the formation);

- presence and quality of cement stone;

- absence of accidents in the well that led to its abandonment;

- no production drilling plans in the considered work area. 

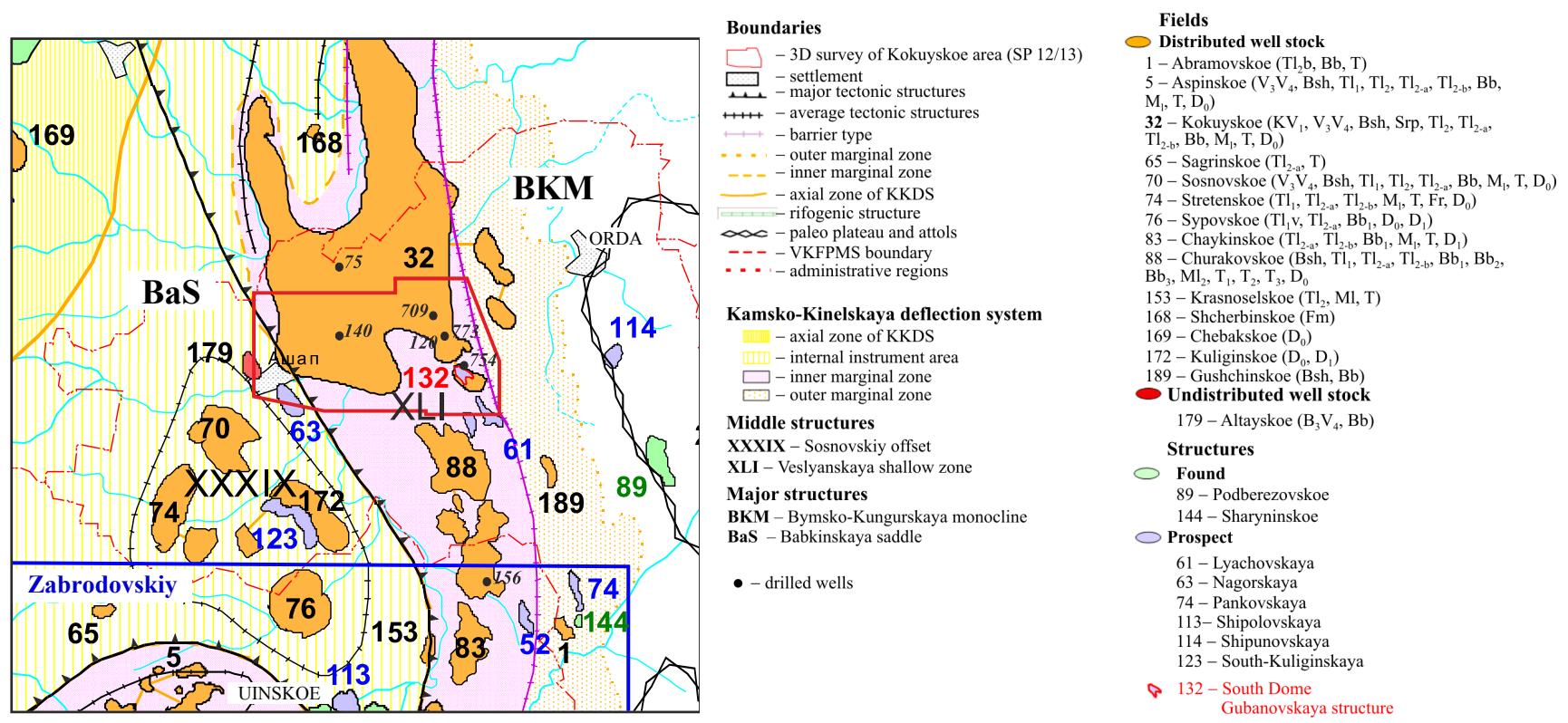

Fig. 1. Schematic map of the work area: KKDS - Kamsko-Kinelskaya deflection system;

VKFPMS - Verkhnekamskoe field of potassium and magnesium salts

Table 1

Basic well information*

\begin{tabular}{|c|c|}
\hline Name & Value \\
\hline Field (uplift) & Kokuyskoe (Gubanovskoe) \\
\hline Well cluster & 4 \\
\hline Well number & 754 \\
\hline Altitude of the rotor table, $\mathrm{m}$ & 215.24 \\
\hline Well category & Oil in suspension \\
\hline Well category by hazard & $2^{\text {nd }}(\mathrm{GF})$ \\
\hline Operational formation & Bsh \\
\hline $\begin{array}{l}\text { Well construction: } \\
\text { - surface } \varnothing 426 \times 11 \mathrm{~mm} \\
\text { - conductor Ø } 299 \times 9 \mathrm{~mm} \\
\text { - intermediate casing } \varnothing 219 \times 8 \mathrm{~mm} \\
\text { - production string } \varnothing 146 \times 8 \mathrm{~mm} \\
\end{array}$ & $\begin{array}{l}21 \mathrm{~m}, \mathrm{HCV} \text { to well head } \\
70 \mathrm{~m}, \mathrm{HCV} \text { to well head } \\
498 \mathrm{~m}, \mathrm{HCV} \text { to well head } \\
1825 \mathrm{~m}, \mathrm{HCV} \text { up to } 220 \mathrm{~m}\end{array}$ \\
\hline $\begin{array}{l}\text { Perforation intervals, } \mathrm{m:} \\
- \text { Bsh } \\
-\mathrm{Tl}\end{array}$ & $\begin{array}{c}1382.0-1392.0 \mathrm{~m} \text { (not isolated) } \\
1729.0-1735.0 \mathrm{~m} \text { (isolated 10/22/1986) }\end{array}$ \\
\hline Drilled bottom hole, $\mathrm{m}$ & 1825.0 \\
\hline Artificial bottomhole, $\mathrm{m}$ & 1810.0 \\
\hline Current bottomhole, $\mathrm{m}$ & 1592.0 \\
\hline Maximum zenith angle, degree & 29.25 degrees at a depth of $300 \mathrm{~m}$ \\
\hline The state of the cement stone behind the casing & Satisfactory \\
\hline Casing tightness, MPa, its residual strength & 13.0 (defined 07/07/1976) \\
\hline Presence of cross flows & - \\
\hline The presence (absence) of pressure in the annular spaces, MPa & - \\
\hline Underground equipment & - \\
\hline Wellhead equipment & ETG $73 \times 146$ \\
\hline Well state & Suspension \\
\hline
\end{tabular}

Note: ${ }^{*}$ - information may be changed to maintain confidentiality; ULC - upper limit of cementing. 


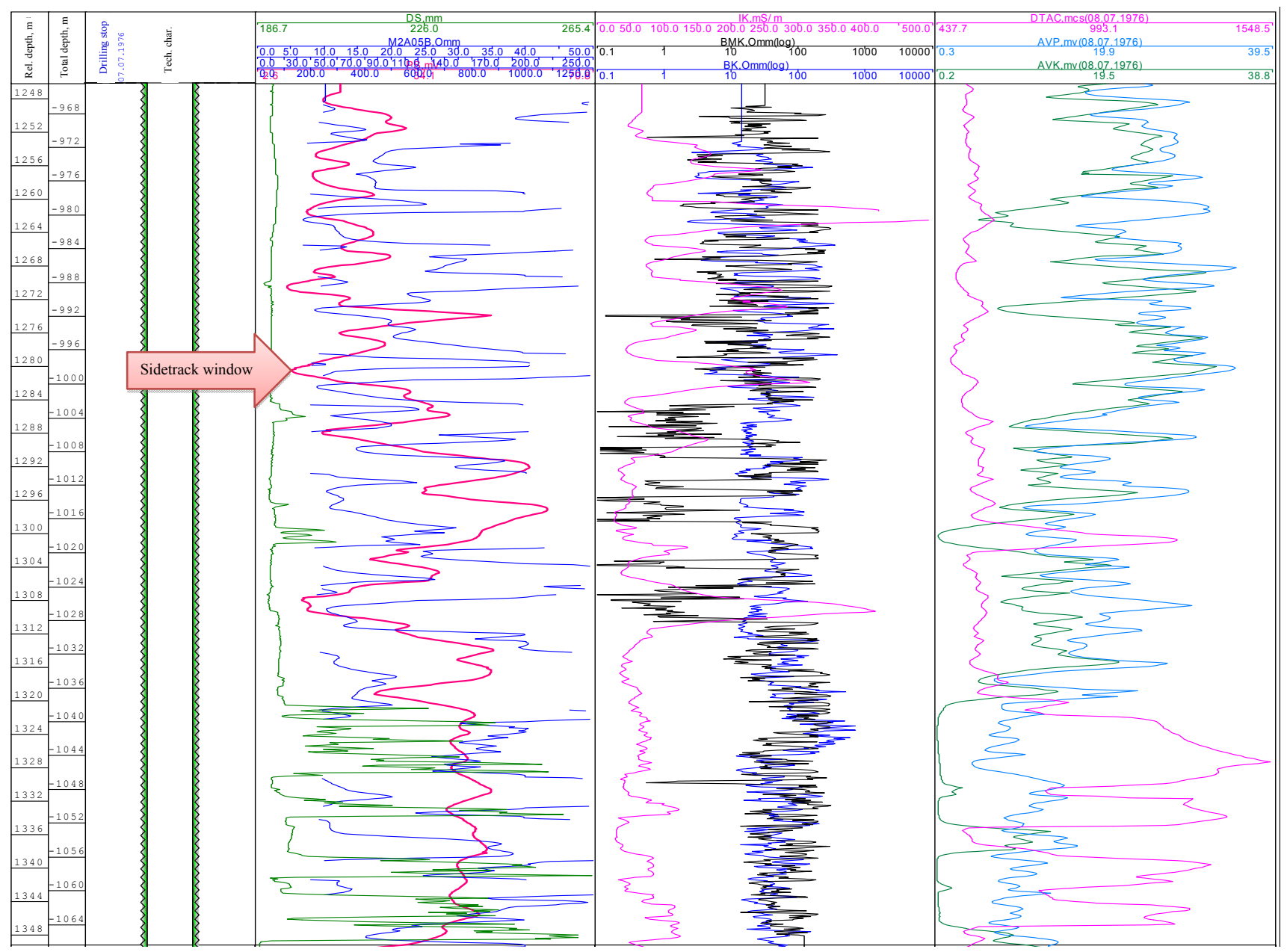

Fig. 2. Selection of the interval of drilling the well according to the logging data

When choosing a second wellbore interval, the following criteria are used [25]:

- depth from the well head to the upper edge of the last perforated interval, the second trunk is drilled 30-50 m higher accordingly;

- presence and quality of a cement stone behind the casing;

- well wall resistance and minimum rock hardness;

- maximum intensity of the curvature of the wellbore above the drilling interval (should not exceed $2-3^{\circ}$ per $10 \mathrm{~m}$ );

- depth of clutches of the production string in the interval of the intended cut;

- tightness of the production string in the estimated interval;

- depth of the productive formation roof;

- deviation of the trunk from the vertical;
- radius of curvature in the section of zenith angle set.

The third stage includes preparation of drilling geodata. As a result of the calculation, the exact values of location, angles and preliminary depth of the sidetrack are determined. The current owner of the land on which the well is located is established. In the presence of a valid lease agreement for a land plot, it becomes possible to perform work without a long process of land acquisition and associated costs.

Based on geodata, profiles for recommended stems were calculated.The first consideration was the possibility of oblique drilling with a maximum zenith angle of up to $60^{\circ}$ (Table 2). This solution is associated with the possibility of using clayless or thin mud, which will also reduce the cost of drilling [26-35]. Well profiles should take into 
account the presence of a significant zenith angle drop along the section while drilling promising deposits [36, 37].

Profiles of sidetracks were constructed, allowing in three-dimensional form to represent the passage of the projected profile through structural surfaces (Fig. 3, 4).

Thanks to the received images, it is possible to check the correctness of profile construction and correct them for the most optimal posting.

Due to the fact that the sidetracks perform the functions of wildcat, appraisal and exploration wells, establishment of an optimal set of geological and geophysical studies is one of the most important points. In order to obtain high-quality geological information in the planorder it is planned to include an expanded complex of well logs (Table 3 ). To study the lithological characteristics of the layers and physical properties of reservoirs, clarify the stratigraphic boundaries, effective and oilsaturated thickness, the position of oil-water contacts, as well as laboratory studies in wells, core sampling is provided. Well test during the drilling process with the help of KII-92 equipment is also planned [38].

Core sampling is recommended to be carried out using the Security DBS 104/52 core drilling tool or its analogs with collet type core breakers providing $100 \%$ core removal.

To study the lithology of the section and determine the oil content in it, sludge is sampled after $5 \mathrm{~m}$ of penetration, in productive intervals at $2 \mathrm{~m}$. The control measurement of the tool should be carried out before coring and after reaching the design depth of the well.

Table 2

Well inclinometry report for 754 Kokuyskoe field

(analysis range for the wellbore - from 1280 to $2552.33 \mathrm{~m}$ )

\begin{tabular}{|c|c|c|c|c|c|c|c|c|c|c|c|}
\hline $\begin{array}{l}\Xi \\
\text { है } \\
00 \\
0 \\
\overline{0} \\
\overline{0}\end{array}$ & 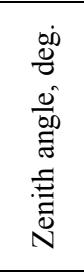 & 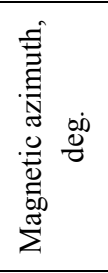 & 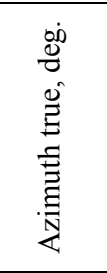 & 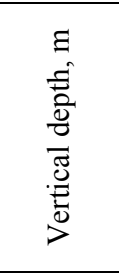 & 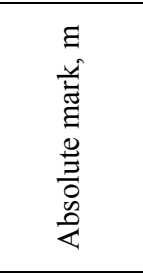 & 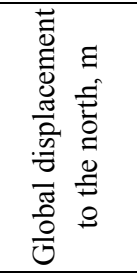 & 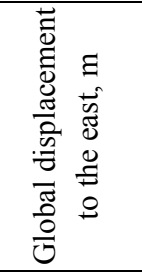 & 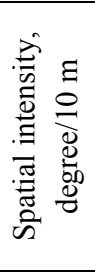 & 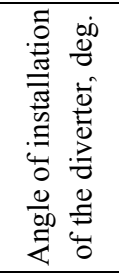 & 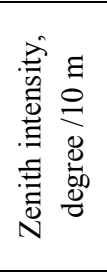 & 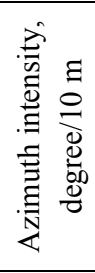 \\
\hline 1280.00 & 8.75 & 137.13 & 137.13 & 1213.24 & -997.90 & 50444.40 & 46472.63 & 0.152 & -90.49 & 0.000 & -1.000 \\
\hline 1290.00 & 9.75 & 151.43 & 151.43 & 1223.11 & -1007.77 & 50443.09 & 46473.57 & 2.507 & 66.49 & 1.000 & 14.300 \\
\hline 1300.00 & 9.75 & 151.43 & 151.43 & 1232.97 & 1017.63 & 50441.61 & 46474.38 & 0.000 & 0.00 & 0.000 & 0.000 \\
\hline 1455.08 & 56.81 & 223.20 & 223.20 & 1361.61 & 1146.27 & 50377.93 & 46433.10 & 3.500 & 78.25 & 3.035 & 4.628 \\
\hline 1935.04 & 56.81 & 223.20 & 223.20 & 1624.34 & 1409.00 & 50085.14 & 46158.14 & 0.000 & 0.00 & 0.000 & 0.000 \\
\hline 2552.33 & 2.37 & 223.20 & 223.20 & 2141.16 & 1925.82 & 49871.20 & 45957.25 & 0.882 & -180.00 & -0.882 & 0.000 \\
\hline
\end{tabular}
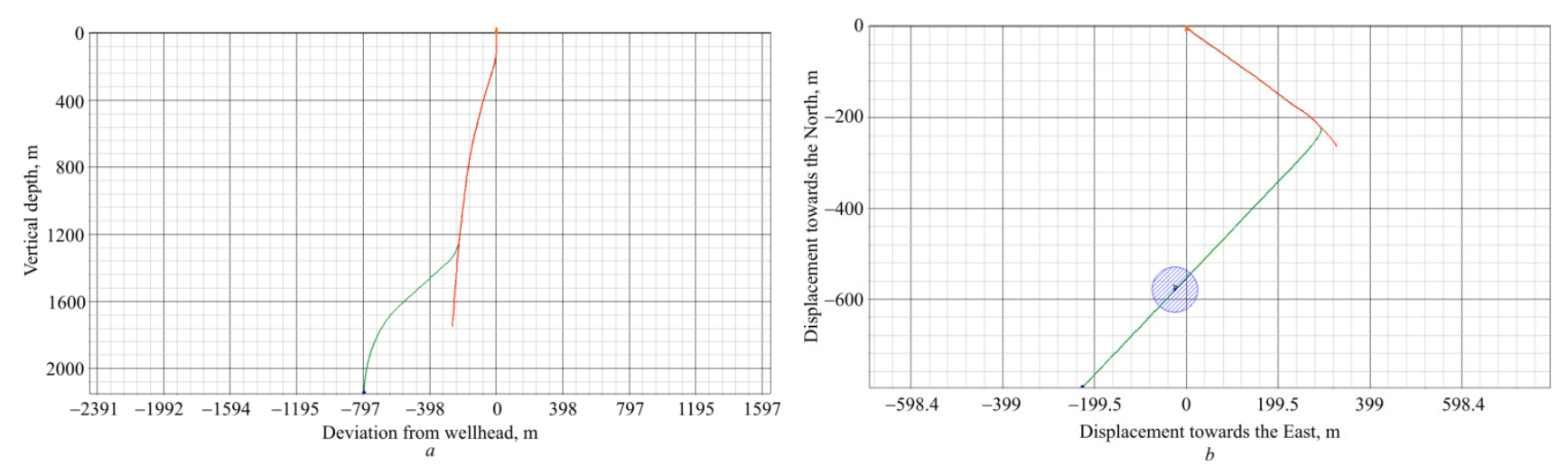

Fig. 3. Vertical (a) and horizontal $(b)$ sidetrack projections 


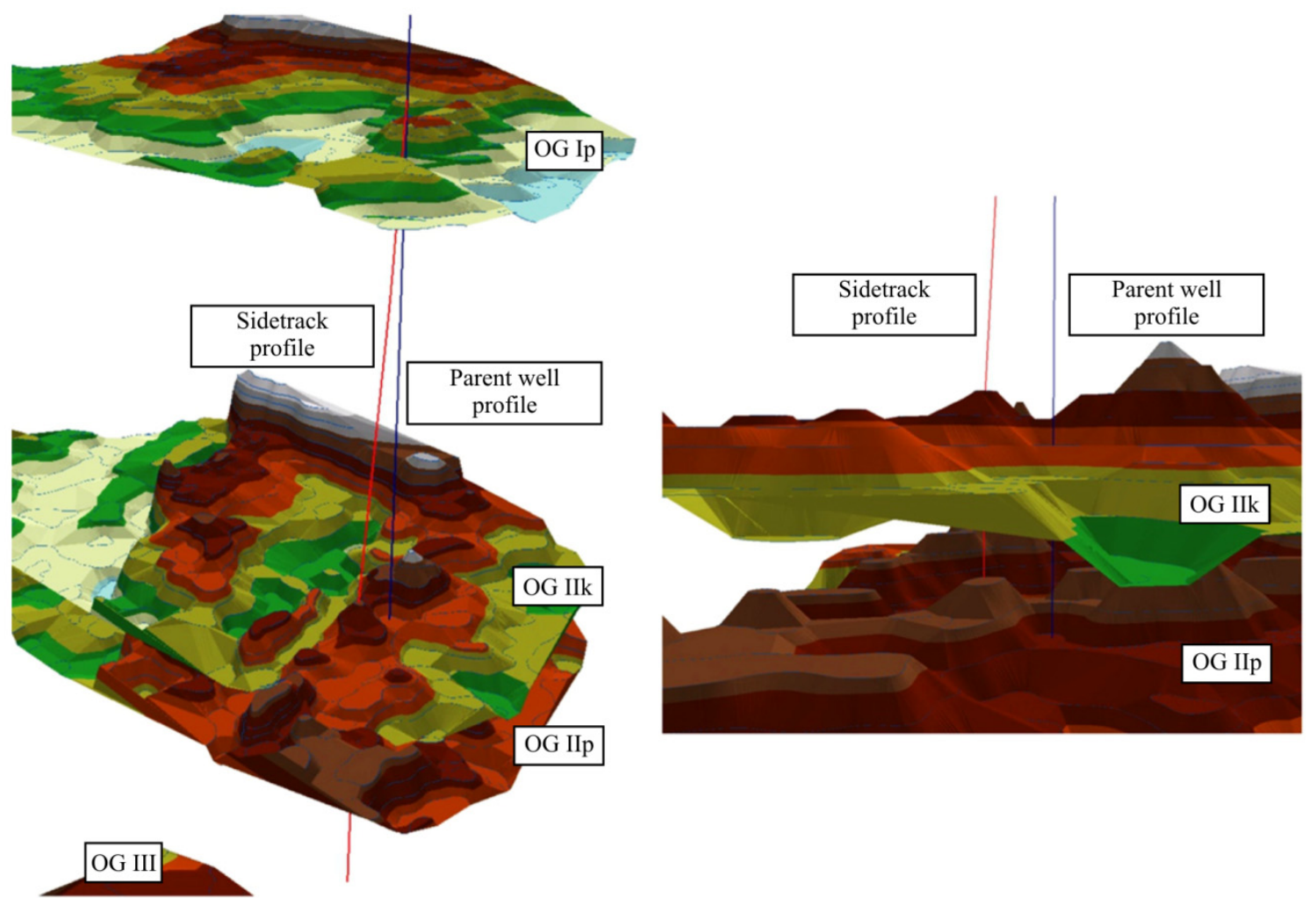

Fig. 4. Building a profile of the projected sidetrack relative to the main reflecting intervals

Table 3

Well logging

\begin{tabular}{|l|c|c|}
\hline \multicolumn{1}{|c|}{ Test type* } & Recording scale & Notes \\
\hline $\begin{array}{l}\text { LG-5, GRL, NNL, IL, LL, } \\
\text { AL ith VS, Caliper, GGRL-LDL, MP, MLL, EPTL, NGSL }\end{array}$ & $1: 200$ & Intermediate logging after subsurface coal deposits \\
\hline $\begin{array}{l}\text { GRL, NNL, AL with VS, Caliper, GGRL-LDL } \\
\text { LG-5, IL, LL, MLL, MP, Caliper, GRL, NNL, AL ith VS, } \\
\text { GGRL-LDL, EPTL, NGSL }\end{array}$ & $1: 500$ & After well drilling \\
\hline GRL, NNL, Caliper & $1: 200$ & Binding logging before coring \\
\hline GRL, NNL, LL, Caliper & $1: 200$ & $\begin{array}{c}\text { Binding logging before reservoir testing by pipe } \\
\text { testers }\end{array}$ \\
\hline \multicolumn{2}{|c|}{ Complex of tests on control of technical condition of wells } \\
\hline CBL, GRCM (WGRDT), EMITM & $1: 500$ & $\begin{array}{c}\text { Throughout the entire wellbore no earlier than 48 } \\
\text { hours after the launch of the production string }\end{array}$ \\
\hline CBL-S, GRCM (WGRDT), EMITM & $1: 200$ & In the intervals of detailed studies \\
\hline
\end{tabular}

Note: * the list of acronyms of the types of studies is presented in the "Technical Instructions for Geophysical Research and Instrumentation on Cable in Oil and Gas Wells RD 153-39.0-072-01”, approved by the Ministry of Natural Resources, Order No. 134 of 07.05.2001.

The cost and payback period of capital investments for sidetracks construction is significantly lower than the similar rates of drilling a new well due to the use of a part of existing well and field infrastructure. The feasibility study revealed that the planned works satisfy the conditions for the effectiveness of
LUKOIL PJSC projects and can be recommended for implementation [39].

Thus, the implementation of proposals will minimize costs associated with reserves increase, and the time to enter into the development of newly discovered reserves will be reduced. 


\section{References}

1. Popova K.V., Dodonova L.S., Gabnasyrov A.V., Solovev S.I., Sulima A.I., Bezukladnikov A.N., Putilov I.S., Nazarov A.Yu., Pyatunina E.V. Analiz pozitivnogo i negativnogo vliyaniya razryvnykh narusheniy na sokhrannost zalezhey uglevodorodov na yugo-vostoke Permskogo kraya [Analysis of faults' positive and negative influence on undamaged state of hydrocarbon deposits in the south-east of Perm region]. Geology, Geophysics and Development of Oil and Gas Fields, 2017, no.10, pp.4-11.

2. Boyarshinova M.G., Vinokurova E.E., Pyatunina E.V. Osobennosti litologo-fatsialnogo stroeniya karbonatnoy tolshchi famenskogo yarusa Zabrodovskoy ploshchadi $\mathrm{v}$ svyazi s perspektivami neftegazonosnosti [Discussion of some specific features of lithological-facial structure of carbonate strata of famennian stage of Zabrodovsky territory because of prospects of its oil and gas potential]. Geology, Geophysics and Development of Oil and Gas Fields, 2015, no.4, pp.10-12.

3. Galkin V.I., Kozlova I.A., Krivoshchekov S.N., Pyatunina E.V., Pestova S.N. O vozmozhnosti prognozirovaniya neftegazonosnosti famenskikh otlozheniy $\mathrm{S}$ pomoshchyu postroeniya veroyatnostno-staticheskikh modeley [On the possibility of predicting the petroleum potential of Famennian sediments using the construction of probabilistic-static models]. Geology, Geophysics and Development of Oil and Gas Fields, 2007, no.10, pp.22-27.

4. Frik M.G., Batova I.S., Bykova N.V., Khakimova Zh.A. Neftegazovyi potentsial Bereznikovskogo paleoplato (Permskii krai) po geokhimicheskim dannym [Oil and gas potential of the Bereznikovskiy paleoplato (Perm region) according to geochemical data]. Geology, Geophysics and Development of Oil and Gas Fields, 2007, no.8, pp.45-58.

5. Frik M.G., Titova G.I., Batuev I.K., Khakimova Zh.A. Nefti i gazy bereznikovskogo paleoplato na severe Permskogo kraia [Oil and gases of the Berezniki paleoplato in the north of the Perm region]. Geology, Geophysics and Development of Oil and Gas Fields, 2007, no.11, pp.11-16.

6. Putilov I.S., Vinokurova E.E., Khakimova Zh.A. Izuchenie razmeshcheniya effektivnykh tolshchin vizeyskikh terrigennykh otlozheniy Bashkirskogo svoda po rezultatam interpretatsii seysmorazvedki 3D [Studying of regularities of efficient thicknesses location of Visean terrigenous formations of Bashkir fold on the basis of data interpretation of 3D seismic survey]. Geology, Geophysics and Development of Oil and Gas Fields, 2012, no.4, pp.49-53.
7. Piatunina E.V., Khakimova Zh.A., Neganov V.M. Osobennosti razvitiia kollektorov vizeiskoi terrigennoi tolshchi i perspektivy ikh obnaruzheniia na iugo-vostoke Permskogo kraia [Features of development of reservoirs of the Visean terrigenous sequence and prospects for their discovery in the south-east of the Perm region]. Geology, Geophysics and Development of Oil and Gas Fields, 2007, no.10, pp.27-32.

8. Ust'kachkincev E.N. Increase productivity of construction in sidetrack of Verkhnekamsk potassiummagnesium salts field. Perm Journal of Petroleum and Mining Engineering, 2012, vol.11, no.5, pp.39-46c.

9. Zaboeva M.I., Suerov B.A., Laputina E.S., Zotova O.P. Effektivnost nefteizvlecheniia skvazhin s bokovymi stvolami [Efficiency of oil recovery of wells with side tracks]. Akademicheskiy zhurnal Zapadnoy Sibiri, 2014, vol.10, no.1(50), pp.119-120.

10. Filatov M.A., Ryabchevskikh M.Yu. Obosnovanie effektivnosti bokovykh stvolov pri mnogovariantnom geologo-gidrodinamicheskom modelirovanii na osnove geologo-promyslovogo analiza [Justification of the efficiency of side tracks in case of multivariate geological and hydrodynamic modeling based on geological field analysis]. Problemy razrabotki mestorozhdeniy uglevodorodnykh i rudnykh poleznykh iskopaemykh, 2015, no.1, pp.168-172.

11. Bariev O.I. Modelirovanie bokovykh stvolov [Sidetrack modelling]. Akademicheskiy zhurnal Zapadnoy Sibiri, 2015, vol.11, no.2(57), pp.13-14.

12. Raspopov A.V., Kazantsev A.S., Leontev D.V., Letunova S.V. Kompleksnyy podkhod $\mathrm{k}$ planirovaniyu bokovykh stvolov [Integrated approach to sidetracking planning]. Geology, Geophysics and Development of Oil and Gas Fields, 2015, no.12, pp.52-55.

13. Raspopov A.V., Shiryaev Yu.Kh., Danilenko G.G., Galitsina N.S., Mikheeva T.P. Povyshenie effektivnosti razrabotki mestorozhdeniy na zavershayushchey stadii bureniem dopolnitelnykh stvolov [Improving the efficiency of field development at the final stage by drilling additional tracks]. Oil industry, 2001, no.7, pp.51-53.

14. Kulikov S.V. Kapitalnyy remont skvazhin zarezkoy bokovykh stvolov [Well workover with sidetracking]. Neft. Gaz. Novatsii, 2011, no.12, pp.71-75.

15. Gilyazov R.M. Burenie neftyanykh skvazhin s bokovymi stvolami [Drilling of oil wells with sidetracks]. Moscow, Nedra-Biznestsentr, 2002, 255 p.

16. Kolba P., Klimov M. Sidetrack and well deepening operations in the Jurassic Formation of 
Vyngapur oil field. SPE, 2010, Oct, pp.26-28. DOI: 10.2118/138061-RU

17. Varushkin S.V. Proekt dorazvedki famenskikh otlozheniy putem bureniya bokovykh stvolov i uglubleniya skvazhin proektnogo ekspluatatsionnogo fonda OOO "LUKOYL-PERM" [he supplementary exploration project for the Famennian deposits by drilling lateral shafts and deepening wells of the design operational fund of LUKOIL-PERM LLC]. Geologiya v razvivayushchemsya mire. Ed. R.R. Gilmutdinov. Perm, Permskiy gosudarstvennyy natsionalnyy issledovatelskiy universitet, 2017, vol.1, pp.196-197.

18. Pravila bezopasnosti v neftyanoy i gazovoy promyshlennosti [Safety rules in oil and gas industry], available at: https://tk-servis.ru/uploads/files/ntd20150306- 203247.pdf (accessed 12 Februar 2018).

19. Buslaev V.F. Tekhniko-tekhnologicheskie resheniya po stroitelstvu gorizontalnykh i razvetvlennykh skvazhin [Technical and technological solutions for construction of horizontal and multilateral wells]. Burenie skvazhin, 1992, no.10, pp.8-12.

20. Clements W.R., Jelsma H.H. Horizontal wells pose special hydraulic design considerations. Petroleum Engineer International. 1989, 61(11), pp.45-51.

21. Crouse P.C. Horizontal drilling spurs optimism. World Oil, 1991, vol.212, no.2, pp.35-37.

22. Skelton J.H. Louisiana horisontal well taps oil in area of salt related fracturing. Oil and Gas $J, 1992$, vol.90, no. 27 , pp.88-90.

23. Akhtyamov R.A., Safiullin I.R., Khakimov R.V., Khakimov V.S. Osobennosti zarezki dopolnitelnogo stvola $\mathrm{v}$ ekspluatatsionnoy kolonne skvazhiny [Features of additional borehole drilling in a production string]. Stroitelstvo neftyanykh i gazovykh skvazhin na sushe i na more, 2014, no.3, pp.15-18.

24. Tipovye tekhniko-tekhnologicheskie resheniya na burenie bokovykh stvolov iz ekspluatatsionnykh skvazhin na osnove ispolzovaniya sovremennykh tekhnicheskikh sredstv i tekhnologiy [Typical technical and technological solutions for drilling sidetracks from production wells based on use of modern technical means and technologies]. Moscow, OAO NK "LUKOYL", 2005.

25. Shenberger V.M., Zozulya G.P., Geykhman M.G., Matieshin I.S., Kustyshev A.V. Tekhnika i tekhnologiya stroitelstva bokovykh stvolov v neftyanykh i gazovykh skvazhinakh [Technique and technology of the construction of sidetracks in oil and gas wells]. Tyumen, Izdatelstvo tyumenskogo gosudarstvennogo neftegazovogo universiteta, 2006, $573 \mathrm{p}$.

26. Aadnoy B.S., Chenevert M.E. Stability of highly inclined bore-holes. SPE Drilling Engineering, 1987, vol.2, iss.04, pp.364-374. DOI: 10.2118/16052-PA
27. Gray G.R., Darly H.C., Rogers W.F. Composition and properties of oil well drilling fluids. Houston, Gulf Publishing Co., 1980, $630 \mathrm{p}$.

28. Al-Ajmi A.M., Zimmerman R.W. A new well path optimization model for increased mechanical borehole stability. Journal of Petroleum Science and Engineering, 2009, vol.69, iss.1-2, pp.53-62, DOI: $10.1016 /$ j.petrol.2009.05.018

29. Chen X., Tan, C.P., Detournay C. A study on wellbore stability in fractured rock masses with impact of mud infiltration. Journal of Petroleum Science and Engineering, 2003, vol.38, iss.3-4, pp.145-154. DOI: $10.1016 / \mathrm{S} 0920-4105(03) 00028-7$

30. Friedel T., Trebolle R.L., Flew S., Belfield W., Syaifullah N., Curteis C., Meyer J., Caretta F. An integrated computer based method to maximize infill drilling, sidetracking and workover potential in multiple stacked hydrocarbon reservoirs. Asia Pacific Oil and Gas Conference \& Exhibition, 4-6 August, Jakarta, Indonesia, 2009, p.18. DOI: 10.2118/123711-MS

31. Zeynali M.E. Mechanical and physico-chemical aspects of wellbore stability during drilling operations. Journal of Petroleum Science and Engineering, 2012, vol.82-83, pp.120-124. DOI: $10.1016 / j$.petrol.2012.01.006

32. Kleverlaan M., Lawless A. Through tubing rotary drilling: a cost-effective method for sidetracking wells in mature assets. SPE Annual Technical Conference and Exhibition, 26-29 September, Houston, Texas, 2004. DOI: $10.2118 / 91005-\mathrm{MS}$

33. Palomino D., Pinard C., Steinke S., Moss B. Milling reliability curves as decision-making tools in cased hole sidetracking applications. IADC/SPE Asia Pacific Drilling Technology Conference, Society of Petroleum Engineers, 22-24 August 2016, Singapore. DOI: $10.2118 / 180525-\mathrm{MS}$

34. Garfield G.L., Mackenzie G. Latest developments and new technologies for coiled-tubing sidetracking applications. IADC/SPE Drilling Conference, Society of Petroleum Engineers, 4-6 March 2008, Orlando, Florida, USA. DOI: $10.2118 / 112587-M S$

35. Smalley M.T., Teale D.W., Haq M.A. Workover well operations to restore full reservoir access in an underground natural-gas-storage cavern: a case study for developing new technology in dual-string section milling methods. SPE Western Regional Meeting, Society of Petroleum Engineers, 23-27 April 2017, Bakersfield, California. DOI: $10.2118 / 185702-M S$

36. Povalikhin A.S., Kovalenko V.V., Solodkiy K.M. Voprosy proektirovaniya prostranstvennogo profilya gorziontalnykh skvazhin i bokovykh stvolov [Questions on design of the spatial profile of horizontal wells and 
sidetracks]. Stroitelstvo neftyanykh i gazovykh skvazhin na sushe i na more, 2012, no.1, pp.8-11.

37. Legaev Ya.V., Khalimov M.A. Profili bokovykh stvolov s gorizontalnym okonchaniem i vybor traektorii bureniya dlya snizheniya zatrat pri stroitelstve bokovykh stvolov [Profiles of side tracks with a horizontal end and way to select drilling path in order to reduce costs of sidetracking]. Oilfield engineering, 2008, no.3, pp.35-40.

38. Akhtyamov R.A., Safiullin I.R., Khakimov R.V., Khakimov V.S. Osobennosti interpretatsii rezultatov

issledovaniya bokovykh stvolov ispytatelyami plastov na trubakh [Some peculiarities of data interpretation received during lateral holes studying by means of layer pipe testers]. Geology, Geophysics and Development of Oil and Gas Fields, 2011, no.5, pp.35-39.

39. Volkova O.A., Lobanov D.S., Poplauhina T.B. The reserves increase account due to well side tracking in petroleum geological and economic evaluation according to international standards. Perm Journal of Petroleum and Mining Engineering, 2012, vol.11, no.3, pp.94-103.

\section{Библиографический список}

1. Анализ позитивного и негативного влияния разрывных нарушений на сохранность залежей углеводородов на юго-востоке Пермского края / К.В. Попова, Л.С. Додонова, А.В. Габнасыров, С.И. Соловьев, А.И. Сулима, А.Н. Безукладников, И.С. Путилов, А.Ю. Назаров, Е.В. Пятунина // Геология, геофизика и разработка нефтяных и газовых месторождений. - 2017. - № 10. - С. 4-11.

2. Бояршинова М.Г., Винокурова Е.Е., Пятунина Е.В. Особенности литолого-фациального строения карбонатной толщи фаменского яруса Забродовской площади в связи с перспективами нефтегазоносности // Геология, геофизика и разработка нефтяных и газовых месторождений. - 2015. - № 4. - С. 10-12.

$3 . \mathrm{O}$ возможности прогнозирования нефтегазоносности фаменских отложений с помощью построения вероятностно-статических моделей / В.И. Галкин, И.А. Козлова, С.Н. Кривощеков, Е.В. Пятунина, С.Н. Пестова // Геология, геофизика и разработка нефтяных и газовых месторождений. 2007. - № 10. - С. 22-27.

4. Нефтегазовый потенциал Березниковского палеоплато (Пермский край) по геохимическим данным / М.Г. Фрик, И.С. Батова, Н.В. Быкова, Ж.А. Хакимова // Геология, геофизика и разработка нефтяных и газовых месторождений. - 2007. № 8. - C. 45-58.

5. Нефти и газы Березниковского палеоплато на севере Пермского края / М.Г. Фрик, Г.И. Титова, И.К. Батуев, Ж.А. Хакимова // Геология, геофизика и разработка нефтяных и газовых месторождений. 2007. - № 11. - С. 11-16.

6. Путилов И.С., Винокурова Е.Е., Хакимова Ж.А. Изучение размещения эффективных толщин визейских терригенных отложений Башкирского свода по результатам интерпретации сейсморазведки 3D // Геология, геофизика и разработка нефтяных и газовых месторождений. - 2012. - № 4. - С. 49-53.
7. Пятунина Е.В., Хакимова Ж.А., Неганов В.М. Особенности развития коллекторов визейской терригенной толщи и перспективы их обнаружения на юго-востоке Пермского края // Геология, геофизика и разработка нефтяных и газовых месторождений. 2007. - № 10. - С. 27-32.

8. Устькачкинцев Е.Н. Повышение эффективности строительства боковых стволов на территории Верхнекамского месторождения калийно-магниевых солей // Вестник Пермского национального исследовательского политехнического университета. Геология. Нефтегазовое и горное дело. - 2012. - Т. 11, № 5. C. $39-46$.

9. Эффективность нефтеизвлечения скважин с боковыми стволами / М.И. Забоева, Б.А. Суеров, Е.С. Лапутина, О.П. Зотова // Академический журнал Западной Сибири. - 2014. - Т. 10, № 1 (50). С. 119-120.

10. Филатов М.А., Рябчевских М.Ю. Обоснование эффективности боковых стволов при многовариантном геолого-гидродинамическом моделировании на основе геолого-промыслового анализа // Проблемы разработки месторождений углеводородных и рудных полезных ископаемых. 2015. - № 1. - С. 168-172.

11. Бариев О.И. Моделирование боковых стволов // Академический журнал Западной Сибири. - 2015. T. 11, № 2 (57). - С. 13-14.

12. Комплексный подход к планированию боковых стволов / А.В. Распопов, А.С. Казанцев, Д.В. Леонтьев, С.В. Летунова // Геология, геофизика и разработка нефтяных и газовых месторождений. 2015. - № 12. - С. 52-55.

13. Повышение эффективности разработки месторождений на завершающей стадии бурением дополнительных стволов / А.В. Распопов, Ю.Х. Ширяев, Г.Г. Даниленко, Н.С. Галицина, Т.П. Михеева // Нефтяное хозяйство. - 2001. - № 7. - С. 51-53. 
14. Куликов С.В. Капитальный ремонт скважин зарезкой боковых стволов // Нефть. Газ. Новации. 2011. - № 12. - С. 71-75.

15. Гильязов Р.М. Бурение нефтяных скважин с боковыми стволами. - М.: Недра-Бизнесцентр, 2002. $255 \mathrm{c}$.

16. Kolba P., Klimov M. Sidetrack and well deepening operations in the Jurassic Formation of Vyngapur oil field // SPE. - 2010. - Oct. - P. 26-28. DOI: $10.2118 / 138061-R U$

17. Варушкин С.В. Проект доразведки фаменских отложений путем бурения боковых стволов и углубления скважин проектного эксплуатационного фонда ООО «ЛУКОЙЛ-ПЕРМЬ» // Геология в развивающемся мире: сб. науч. тр.: в 2 т. / отв. ред. Р.Р. Гильмутдинов; Перм. гос. нац. исслед. ун-т. Пермь, 2017. - Т. 1. - С. 196-197.

18. Правила безопасности в нефтяной и газовой промышленности (зарегистрировано в Минюсте России 19.04.2013 № 28222; с изм. и доп. вступ. в силу с 01.01.2017): утв. приказом Федеральной службы по экологическому, технологическому и атомному надзору от 12.03.2013 № 101 [Электронный ресурс]. URL: $\quad$ https://tk-servis.ru/uploads/files/ntd-20150306203247.pdf (дата обращения: 12.02.2018).

19. Буслаев В.Ф. Технико-технологические решения по строительству горизонтальных и разветвленных скважин // Бурение скважин. - 1992. № $10 .-$ C. $8-12$.

20. Clements W.R., Jelsma H.H. Horizontal wells pose special hydraulic design considerations // Petroleum Engineer International. - 1989. - 61 (11). P. 45-51.

21. Crouse P.C. Horizontal drilling spurs optimism // World Oil. - 1991. - Vol. 212, № 2. - P. 35-37.

22. Skelton J.H. Louisiana horisontal well taps oil in area of salt related fracturing // Oil and Gas J. - 1992. Vol. 90, № 27. - P. 88-90.

23. Особенности зарезки дополнительного ствола в эксплуатационной колонне скважины / Р.А. Ахтямов, И.Р. Сафиуллин, Р.В. Хакимов, В.С. Хакимов // Строительство нефтяных и газовых скважин на суше и на море. - 2014. - № 3. - С. 15-18.

24. Типовые технико-технологические решения на бурение боковых стволов из эксплуатационных скважин на основе использования современных технических средств и технологий / ОАО НК «ЛУКОЙЛ». - М., 2005.

25. Техника и технология строительства боковых стволов в нефтяных и газовых скважинах: учеб. пособие / В.М. Шенбергер, Г.П. Зозуля, М.Г. Гейхман,
И.С. Матиешин, А.В. Кустышев. - Тюмень: Изд-во Тюменск. гос. нефтегаз. ун-та, 2006. - 573 с.

26. Aadnoy B.S., Chenevert M.E. Stability of highly inclined bore-holes // SPE Drilling Engineering. - 1987. - Vol. 2, iss. 04. - P. 364-374. DOI: $10.2118 / 16052-P A$

27. Gray G.R., Darly H.C., Rogers W.F. Composition and properties of oil well drilling fluids. - Houston: Gulf Publishing Co., 1980. - 630 p.

28. Al-Ajmi A.M., Zimmerman R.W. A new well path optimization model for increased mechanical borehole stability // Journal of Petroleum Science and Engineering. - 2009. - Vol. 69, iss. 1-2. - P. 53-62. DOI: $10.1016 /$ j.petrol.2009.05.018

29. Chen X., Tan, C.P., Detournay C. A study on wellbore stability in fractured rock masses with impact of mud infiltration // Journal of Petroleum Science and Engineering. - 2003. - Vol. 38, iss. 3-4. - P. 145-154. DOI: $10.1016 / \mathrm{S} 0920-4105(03) 00028-7$

30. An integrated computer based method to maximize infill drilling, sidetracking and workover potential in multiple stacked hydrocarbon reservoirs / T. Friedel, R.L. Trebolle, S. Flew, W. Belfield, N. Syaifullah, C. Curteis, J. Meyer, F. Caretta // Asia Pacific Oil and Gas Conference \& Exhibition, 4-6 August. - Jakarta, Indonesia. - 2009. - Aug. - P. 18. DOI: $10.2118 / 123711-\mathrm{MS}$

31. Zeynali M.E. Mechanical and physicochemical aspects of wellbore stability during drilling operations // Journal of Petroleum Science and Engineering. - 2012. - Vol. 82-83. - P. 120-124. DOI: 10.1016/j.petrol.2012.01.006

32. Kleverlaan M., Lawless A. Through tubing rotary drilling: a cost-effective method for sidetracking wells in mature assets // SPE Annual Technical Conference and Exhibition, 26-29 September. - Houston, 2004. DOI: $10.2118 / 91005-\mathrm{MS}$

33. Milling reliability curves as decision-making tools in cased hole sidetracking applications / D. Palomino, C. Pinard, S. Steinke, B. Moss // IADC/SPE Asia Pacific Drilling Technology Conference / Society of Petroleum Engineers, Singapore, 22-24 August 2016. DOI: $10.2118 / 180525-\mathrm{MS}$

34. Garfield G. L., Mackenzie G. Latest developments and new technologies for coiled-tubing sidetracking applications // IADC/SPE Drilling Conference, Society of Petroleum Engineers, 4-6 March 2008, Orlando, Florida. DOI: $10.2118 / 112587-\mathrm{MS}$

35. Smalley M.T., Teale D.W., Haq M.A. Workover well operations to restore full reservoir access in an underground natural-gas-storage cavern: a case study for 
developing new technology in dual-string section milling methods // SPE Western Regional Meeting, Society of Petroleum Engineers, 23-27 April 2017, Bakersfield, California. DOI: 10.2118/185702-MS

36. Повалихин А.С., Коваленко В.В., Солодкий К.М. Вопросы проектирования пространственного профиля горзионтальных скважин и боковых стволов // Строительство нефтяных и газовых скважин на суше и на море. - 2012. - № 1. - С. 8-11.

37. Легаев Я.В., Халимов М.А. Профили боковых стволов с горизонтальным окончанием и выбор траектории бурения для снижения затрат при строительстве боковых стволов // Нефтепромысловое дело. - 2008. - № 3. - С. 35-40.
38. Особенности интерпретации результатов исследования боковых стволов испытателями пластов на трубах / Р.А. Ахтямов, И.Р. Сафиуллин, Р.В. Хакимов, В.С. Хакимов // Геология, геофизика и разработка нефтяных и газовых месторождений. 2011. - № 5. - С. 35-39.

39. Волкова О.А., Лобанова Д.В., Поплаухина Т.Б. Учет прироста запасов от бурения боковых стволов при геолого-экономической оценке запасов по международным стандартам // Вестник Пермского национального исследовательского политехнического университета. Геология. Нефтегазовое и горное дело. - 2012. - Т. 11, № 3. - C. 94-103.

Please cite this article in English as:

Varushkin S.V., Khakimova Zh.A. The design of geological exploration with side track drilling. Perm Journal of Petroleum and Mining Engineering, 2018, vol.18, no.1, pp.16-27. DOI: 10.15593/2224-9923/2018.3.2

Просьба ссылаться на эту статью в русскоязычных источниках следующим образом:

Варушкин С.В., Хакимова Ж.А. Проектирование геолого-разведочных работ методом строительства боковых стволов // Вестник Пермского национального исследовательского политехнического университета. Геология. Нефтегазовое и горное дело. - 2018. - Т.18, №1. - С.16-27. DOI: 10.15593/2224-9923/2018.3.2 